\title{
Critical Review of Social Safety Net in COVID Era Based on Maqashid Sharia Framework: Indonesia Case
}

\author{
Tika Widiastuti $^{1 *}$, Muryani ${ }^{2}$, Puji Sucia Sukmaningrum ${ }^{1}$, Sulistya Rusgianto ${ }^{1}$, \\ Aufar Fadlul Hady ${ }^{5}$ and Anidah Robani ${ }^{3}$ \\ ${ }^{1}$ Sharia Economics Department, ${ }^{2}$ Economics Department, ${ }^{5}$ Accounting Departement, \\ ${ }^{2}$ Center for Languages and Human Development. Faculty of Economy and Business, Airlangga University \\ ${ }^{3}$ Universiti Teknikal Malaysia Melaka \\ *Corresponding Author Email: tika.widiastuti@feb.unair.ac.id
}

\begin{abstract}
The high number of layoffs, bankruptcy, and increased poverty has forced the government to provide Social Safety Nets (SSN) programs to the public suffered from the COVID-19 pandemic. Problems arise when SSN programs failed to reach the basic needs of society. This paper aims to provide a Critical Review Analysis of the SSN program, especially in the COVID19 pandemic, based on the Maqashid Sharia framework. This study used a qualitative approach with a case study analysis to provide a critical review of government policies in managing the COVID 19 pandemic. The data obtained from government policy literature such as Indonesia Laws from March-July 2020. The finding shows that from five aspects of Maqashid Sharia (Protecting Religion, Soul, Intellect/Mind, Heredity and Wealth), the Indonesia Government focuses on protecting the soul and wealth. This problem causes the non-optimal performance of the government when handling COVID 19 pandemics. The paper contributes to the government decision making for the SSN Program based on the the Maqashid Sharia.
\end{abstract}

Keywords: COVID-19, Maqashid Sharia, Social Safety Net

\section{INTRODUCTION}

Since the first case of COVID-19 was recorded on March 2, 2020, according to the Indonesian COVID19 Response Acceleration Task Force, to date as of August 23, 2020, there have been 151,498 confirmed cases, 105,198 recovered, and 6,594 deaths scattered in 34 provinces. In addition to the health consequences, a pandemic also has a massive adverse impact on the economic sector that includes an increase in unemployment, a decline in consumption and production activities and a weakening economic growth of negative $-5.32 \%$ in the second quarter of 2020 (Indonesian Statistics, 2020).

The government has issued various policies to overcome the negative impacts on the economy, one of which is the Social Safety Net (SSN) program. Through the Ministry of Social Affairs, the Indonesian government has created SSN programs for poor and vulnerable families affected by the COVID-19 pandemic. The SSN programs consist of the Family Hope Program (Program Keluarga Harapan/PKH) with 10 Million Beneficiary Families, Pre-Employment Cards for 5.6 million beneficiaries, and the Nine Basic Food Cards (Sembilan Bahan Pokok/SEMBAKO) with a total of 20 million beneficiary families. Apart from these aids, the government provides direct cash assistance and electricity subsidies for the community with an electric power of $450 \mathrm{VA}$ and $900 \mathrm{VA}$ (Ministry of Social Affairs, 2020).

Prior studies document that in developing countries, the SSN programs facilitate structural reforms for the economy by replacing inefficient redistributive elements of other programs to protect the poor and vulnerable who may be disadvantaged (Ravallion, 2003); (Alderman \& Hoddinott, 2007); (Grosh et al., 2008)). The results of this study go in line with Mannan (2010) and Majumder \& Begum (2008), which prove that the SSN program affects positively on improving the social-economic status of the beneficiaries. Furthermore, Gupta et al. (2003) show that the SSN program in the form of food assistance can be the right choice to minimize the severe impacts of poverty. This also supports Sumarto et al. (2004), which found that only SSN in rice subsidies has a positive effect in reducing the risk of poverty.

On the other hand, Zain (1999) explains that the Indonesian government's SSN program must be corrected to obtain the maximum results. The provision of these empowerment funds for the poor is not yet effective. Thus, there must be long-term inclusion of programs such as community empowerment to benefit from the cash/capital assistance. Darwis \& Nurmanaf (2016) argue that for 
the SSN program to run optimally, (1) the government must formulate a clear and directed work plan with better approach, (2) determine priority areas with target maps, and (3) the need for supervision of SSN programs. This study extends the literature by providing SSN based on maqashid sharia framework to reducing poverty and other social-economic problems in pandemic era, especially in the COVID-19 era.

The implementation of SSN programs faces many obstacles, including the distribution problems, the data collection of beneficiaries was not updated, and the absence of supervision in the SSN distribution. The occurrence of these problems indicates that the SSN programs issued by the government are not yet optimal. Up today, there is no SSN distribution model compliant with Sharia. To fill the gap in this literature, this study aimed to provide a critical review of implementing the government's SSN program based on the Maqashid Shariah framework. This study is essential for policymakers to plan SSN programs that are more effective, efficient and right on target.

\section{REVIEW OF LITERATURE}

\subsection{The Concept of Social Safety Net}

Several international organizations have contributed to the definition of the Social Safety Net (SSN). The World Bank (2018) describes SSN as noncontributory measures designed to assist the poor and vulnerable from poverty. SSN can also be called a safety net, social assistance, or social transfer, a big part of social protection for the community. In line with the World Bank, the Asia Development Bank (2000) defines JPS as a non-contribution transfer to the poor or vulnerable without emphasizing risk mitigation. Meanwhile, the International Monetary Fund (2018) describes the SSN as an instrument that aimed to reduce the poor's negative impacts that may result from such reforms.

The International Labor Organization (ILO) (2000) explains that SSN program is only a part of social support, while social support is a part of social security and social security is a part of social protection. According to the Independent Evaluation Group (2011) from the World Bank, the SSN program has five functions, namely reducing poverty and inequality, encouraging more investment in human resources among the poor, enabling the poor to manage risks from shocks originating from individuals, enabling the poor to manage the risks of systemic shocks, and protect the poor in the event of broader economic reforms.
The SSN program is an essential program for the middle to lower class society. These programs provide aid and guarantee protection for parents, children, and persons with disabilities, which are generally more common in developing and less developed countries (Grosh et al., 2008). However, this does not mean that there is no SSN program in developed countries (Tabor, 2002). Countries like Europe, the US, Japan, and Australia also provide cash assistance to the community, subsidized housing, and offer family allowances as a form of social distribution to the poor (Emil, 2006). Data from the World Bank's State of Social Safety Nets (2018) shows that safety nets such as cash assistance, transfers in kind, social pensions, public works, and school feeding programs targeting poor and vulnerable households reduce inequality gap and poverty. The positive impact this safety net also applies to low and middle-income countries.

\subsection{The Concept and Parameter of Maqashid Sharia}

Maqashid Sharia consists of two words, namely Maqashid and Sharia. The word 'maqashid' is the plural form of 'maqshad' which means an intent and purpose. At the same time, Sharia has the meaning of Allah's laws set for humans to become guidelines in achieving happiness in life in the world and the hereafter. Therefore, Maqashid Sharia are the goals to be obtained from the establishment of law (Asafri, 1996). According to Ibn Asyur, there are things that Shari' (Allah) wants to realize beneficial human goals or to maintain the benefit in their specific actions (Mahmood et al. 2012). According to Allal Al Fasi, Maqashid Sharia is the purpose of sharia and secrets set by shari', namely Allah SWT, in every aspect of laws where the essence of sharia's implementation is to realize human benefit (Mahmood et al. 2012).

Asafri (1996) explains that benefits can be realized if five main elements can be maintained. According to Imam Syatibi, the five main elements are religion, soul, descent, mind, and wealth/property. To achieve and maintain the five primary elements, Imam Syatibi divided them into three levels of benefits: daruriyat (primary), hajiyat (secondary), and tahsiniyat (tertiary). Daruriyat is intended to maintain the five essential elements and human life above. Hajiyat is meant to eliminate difficulties or make the maintenance of the five main elements better. In comparison, tahsiniyat is intended so that humans can do their best to perfect the maintenance of the five main elements. 
The development of a Social Safety Net (SSN) is aimed at meeting the community's emergency needs. Emergency needs are necessities that must exist to ensure the survival of the community. This is regulated in Presidential Regulation No.78 of 2015. This regulation determines the Regional Minimum Wage must pay attention to the Decent Living Criteria (Kriteria Hidup Layak/KHL). This criterion covers food \& beverages (11 items), clothing (13 items), housing (26 items), education (2 items), health (5 items), transportation (1 item), and recreation and savings ( 2 items).

The basic needs met through SSN programs in Indonesia emphasize the fulfillment of food and beverage, clothing, and health needs. Meanwhile, when referring to the concept of Maqashid Sharia, Ad-Dharruriyatul Khams, and Chapra (2008) identify five basic human needs for a decent life. These five needs must be fulfilled relate to one another. In comparison, social assistance parameters during the COVID-19 pandemic should ideally protect the five mandatory requirements of the community. These needs are manifested within the Maqashid Sharia framework, as described below:

- Protecting Religion (Hifdzu Ad-Din) (Qotadah, 2020):

a. The availability of proper worship buildings and facilities (these buildings and facilities must apply health protocol established by the government).

b. The synergy between the mosque management, mosque council, Amil Zakat Institution, the government, and other related institutions to optimize the implementation of aid distribution or other social programs.

c. Ensure no regulations limit and obstruct the community from worshiping.

- Protect the Soul (Hifdzu An-Nafs) (Finarti \& Putra, 2015):

a. The availability of health facilities that are affordable and adequate for the community.

b. Access for various information media to educate the importance of maintaining health and hygiene.

c. The implementation of health protocols in public facilities, workplaces, markets, and other crowded places.
- Protect the Mind (Hifdzu Al-Aql) (Finarti \& Putra, 2015) (Chapra, 2008):

a. Fulfillment of basic education needs.

b. The surrounding community can use the facilities related to personal development (soft skills and hard skills).

c. The synergy between education and training service providers and social institutions.

- The protection of family descendants (Hifdzu An-Nasb) (Chapra, 2008):

a. The availability of various education facilities to reduce the rate of stunting, malnutrition, psychological disorders, etc.

b. The availability of rehabilitation facilities, social assistance, and maintenance of social welfare for children with physical and mental disabilities.

c. The synergy between RT, RW, village wares, Indonesian Child Protection Commission, and National Commission on Human Rights to reduce risks in protecting the family and the descendant (domestic violence, child neglect, abortion).

- The protection of Wealth (Hifdzu Al-Maal):

a. The availability of financial and logistical assistance to the affected communities (Maftuchan, 2020).

b. Educating the beneficiaries so that the support provided can be sustained (Muhtadi, 2019).

c. Providing business capital for the community (Itsnanini \& Ritonga, 2017).

\section{RESEARCH METHODOLOGY}

This study aimed to provide critical review of the Social Safety Net (SSN) during the Covid-19 period in Indonesia using the Maqashid Sharia framework. This research use qualitative approace with case study metod. The data used in this research are primary and secondary data. Primary data were obtained from in-depth interviews with 13 informants, 2 focus group discussions (FGD) and observations. Meanwhile, secondary data is in the form of literature and related documents, previous research, and government agency reports. In-depth interview and FGD informants came from 
academics in the field of Islamic Economics, associations, Islamic maqashid experts, regulators, and practitioners. More specifically, the results of the in-depth interviews were reviewed for consistency with the results of documentation studies and other information. This is conducted to maintain the objectivity of the results and minimize biases in this study.

\section{RESULT AND DISCUSSION}

\subsection{The Indonesian Government's Social Safety Net Program/SSN (JPS/Jaring Pengaman Sosial) in dealing with COVID- 19}

The SSN Programs aim at protecting people who experience layoffs and a drastic drop in income below the marginal line of poverty where the community cannot meet the basic needs of life. The SSN Program is needed to increase productivity by providing employment opportunities and essential social assistance, especially health and education (World Bank, 2020). The target recipients of the SSN Program are individuals and families who receive both direct and indirect impacts from the pandemic.

The Ministry of Health allocates Rp. 87.75 trillion and focuses on treating COVID-19 patients, providing salaries for doctors and nurses, and increasing the budget for hospital expenses (Fauzia, 2020). The SSN program that has been implemented by the Ministry of Social Affairs and the Coordinating Ministry for Human Development and Cultural Affairs of the Republic of Indonesia includes:

- Increase the support of beneficiary families through the Family Hope Program by $25 \%$ gradually for 10 million families with a budget of Rp. 37.4 Trillion.

- Launching a basic food (Sembilan Bahan Pokok/SEMBAKO) card worth Rp. 200,000 / month (for 12 months) for 20 million families with a budget of IDR 43.6 trillion.

- Providing electricity subsidies for 31.2 million households:

a. Free electricity costs for 24 million households with $450 \mathrm{VA}$ electricity.

b. $50 \%$ discount for 7.2 million households with 900 VA voltage.

This program spends Rp. 58.2 Trillion for a period of three months, from April to June 2020.
- Issuing Pre-Employment Cards for 5.6 million beneficiaries and receive incentives Rp. 600,000 per month for four months with a budget of Rp. 20 trillion from Indonesia state budget funds.

- Providing social assistance (Bantuan Sosial/BANSOS) in the form of basic needs for DKI Jakarta for 1.3 million families and Bogor, Depok, Tangerang, and Bekasi (Bodetabek) for 600 thousand families. This program has been running from April to June 2020 and spent a budget of Rp. 3.42 Trillion. The recipients of BANSOS must be outside the recipients of the Family Hope Program and the Basic Food Cards.

- Providing cash social assistance (Bantuan Sosial/BANSOS) for 9 million beneficiary families during April - June 2020. Recipients of this assistance must be outside the recipients of the Family Hope Program and Basic Food Cards. This program spends a budget of 16.2 trillion.

- Providing direct cash assistance (Bantuan Langsung Tunai/BLT) for 11 million beneficiary families in the amount of Rp. 600,000 per month for three months. The program targets families outside of the recipients of the Family Hope Program, Sembako BANSOS, Cash BANSOS, and Pre-Employment Cards. This program consumes $35 \%$ of the Village Fund (Dana Desa) following the ministerial regulation 6 clusters in 2020 or Rp. 21.2 Trillion.

The concept of a Social Safety Net in dealing with COVID-19 in Indonesia has been developed since early March 2020, even though the program was only effective in April 2020. The obstacle faced by the government in implementing the program include the unpreparedness of the state apparatus to adapt to significant changes in a short time, causing the mismatch of the information and coordination. Consequently, only $35 \%$ of the budget to be absorbed (as of July 2020).

The result show that there are many mismatches between the concept and implementation. These mismatches include the implementation process, the target beneficiaries, the form of the program, and other deficiencies. These mismatches can be described as follows:

- The support, which should have been given from April to June, was actively distributed once in July, although several regions have received the support twice. 
- The allocation of support was not evenly distributed, many people did not receive the government assistance.

- The non-integration of data for aid recipients between Government Institutions, Social Institutions, Corporate CSR, and Community Associations has resulted in many overlapping cases. Some people do not receive assistance at all.

- The Indonesian Government's SSN program only focuses on consumptive or short-term assistances, there is no sustainable benefit from the support given.

- The wrong type of aid to assist the beneficiary families resulted in making the problems of these families unsolved due to the difference of needs and location of families.

- Of the five components of maqashid sharia, all Dharurriatul Khams must be fulfilled. One element of the maqashid sharia with other parts has an inseparable relationship.
- The mentality of beneficiaries who feel proud of receiving assistance from the government causes the community cannot transform from being aid recipients to aid providers. This requires more encouragement and education for beneficiaries.

\subsection{Critical Review of the Social Safety Net (SSN) Program during the Covid-19 Period based on the Maqashid Sharia Framework}

Referring to the Maqashid Sharia principles, the fulfillment of the needs of religion, soul, mind, descent, and property must be fulfilled to solve society's problems. These five pillars must be measured with parameters to ensure whether the ongoing SSN program follows the concept of Maqashid Sharia. In-depth interviews show several evaluation indicators in implementing the SSN program from the idea of Maqashid Sharia, and described as follows:

TABLE 1. Implementation of JPS assessed from the Islamic Maqashid Framework

\begin{tabular}{|c|c|c|}
\hline \multicolumn{2}{|c|}{ Components of Dharurriyatul Khams } & Conformity \\
\hline \multicolumn{3}{|c|}{ Protecting the Religion (Hifdzu Ad-Din) } \\
\hline 1 & $\begin{array}{l}\text { The availability of proper worship buildings and facilities (these buildings and } \\
\text { facilities must apply health protocol established by the government). }\end{array}$ & Yes \\
\hline 2 & $\begin{array}{l}\text { The synergy between the mosque management, mosque council, Amil Zakat } \\
\text { Institution, the government, and other related institutions to optimize the } \\
\text { implementation of aid distribution or other social programs. }\end{array}$ & No \\
\hline 3 & Ensure no regulations limit and obstruct the community from worshiping. & Yes \\
\hline \multicolumn{3}{|c|}{ Protecting the Soul (Hifdzu An-Nafs) } \\
\hline 1 & $\begin{array}{l}\text { The availability of health facilities that are affordable and adequate for the } \\
\text { community. }\end{array}$ & Yes \\
\hline 2 & $\begin{array}{l}\text { Access for various information media to educate the importance of maintaining } \\
\text { health and hygiene. }\end{array}$ & Yes \\
\hline 3 & $\begin{array}{l}\text { The implementation of health protocols in public facilities, workplaces, markets, } \\
\text { and other crowded places. }\end{array}$ & Yes \\
\hline \multicolumn{3}{|c|}{ Protecting the Mind or intellect (Hifdzu Al-Aql) } \\
\hline 1 & Fulfillment of basic education needs. & Yes \\
\hline 2 & $\begin{array}{l}\text { The surrounding community can use the facilities related to personal development } \\
\text { (soft skills and hard skills). }\end{array}$ & No \\
\hline 3 & $\begin{array}{l}\text { The synergy between education and training service providers and social } \\
\text { institutions. }\end{array}$ & No \\
\hline \multicolumn{3}{|c|}{ Protecting the descent (Hifdzu An-Nasb) } \\
\hline 1 & $\begin{array}{l}\text { The availability of various ongoing education and adequate facilities to reduce the } \\
\text { rate of stunting, malnutrition, psychological disorders, etc. }\end{array}$ & No \\
\hline 2 & $\begin{array}{l}\text { The availability of rehabilitation facilities, social assistance, and maintenance of } \\
\text { social welfare for children with physical and mental disabilities. }\end{array}$ & No \\
\hline
\end{tabular}




\begin{tabular}{|l|l|c|}
\hline 3 & $\begin{array}{l}\text { The synergy between RT, RW, village wares, Indonesian Child Protection } \\
\text { Commission, and National Commission on Human Rights to reduce risks in } \\
\text { protecting the family and the descendant (domestic violence, child neglect, } \\
\text { abortion). }\end{array}$ & No \\
\hline \multicolumn{2}{|l|}{ Protecting wealth/property (Hifdzu al-Maal) } & Yes \\
\hline 1 & The availability of financial and logistical assistance to the affected communities & No \\
\hline 2 & Educating the beneficiaries so that the support provided can be sustained. & Yes \\
\hline 3 & Providing business capital for the community & \\
\hline
\end{tabular}
Source : Primary data processed by Author (2020).

Referring to the Maqashid Sharia concept, the distribution of aid must meet humans' minimum necessities of life. Decree of the Minister of Labor and Transmigration No. 13/2012 Article 1a is "the standard for a single worker/laborer to have a decent life physically for one month" (Permenakertrans, 2012). Meanwhile, Maqashid Sharia more comprehensively defines human needs at Dharurriyah, Hajjiyah, Tahsiniyah (Zakaria, Yusoof \& Sanusi, 2019).

Dharrurriyah refers to the primary and most essential needs that must exist in human life (Zakaria \& Malek, 2014). Dharurriyah needs must be fulfilled because otherwise, it will threaten one's life. The requirements that must be met include, among others, the needs of religion, soul, mind, descent, and property. Therefore, an SSN program should meet the five needs required by the maqashid sharia because these five needs are interrelated.

Chapra (2008) explains that the five needs required by maqashid sharia must be related to one another to achieve prosperity. A society's welfare can be realized if the spiritual or non-material aspects of life are fulfilled. If spiritual needs are properly fulfilled, the community's motivation in applying Islamic values in daily life would be higher. Consequently, the role of socio-economic, judicial, and financial institutions in realizing a just socioeconomic life order can be realized.

Furthermore, Chapra (2008) states that the needs for basic education, self-development, and training facilities must be appropriately met. If these needs are not met, it will be challenging for the community to contribute to accelerating sustainable development and achieve prosperity. The absence of freedom of thought and expression, workers do not get their rights, and the lack of financial resources makes people difficult to obtain higher education. Therefore, the Quran and the Sunnah have placed great emphasis on education, Rasulullah peace be upon him (PBUH) says,

$$
\text { "To seek knowledge is mandatory for every }
$$

Muslim" (Narrated by Ibn Majah no. 224 from Anas bin Malik radhiyallahu 'anhu, stated by Al Albani in Shahiih al-Jaami'ish Shaghiir no. 3913)

The protection of religion and the protection of the mind (intellect) are interrelated and inseparable needs. The combination of the two will increase people's understanding of moral values in social life, improve their skills to earn a living, and provide opportunities to contribute to the development of science and technology (Chapra, 2008). Therefore, the government in Indonesia must ensure the need to protect religion and mind that should be manifested in the SSN programs.

Furthermore, regarding the protection of offspring, the family is the first madrasah for a child. If parents fail to teach their child good character traits (khuluq hasan), it will be difficult for them to overcome obstacles that arise in the future. So that since childhood, a child must have primary and moral education, adequate nutrition, and other rights. The state should guarantee these needs (Chapra, 2008). In a hadith narrated by Al-Hakim, the Prophet PBUH says:

$$
\text { حسن أدب من أفضل ولاه والد نحل ما }
$$

"There is no greater gift from parents to

their children than a good education." (HR. Al Hakim: 7679).

The results show that the SSN program policy only focused on protecting life and property. This indicates that fulfillment of two of the five aspects of maqashid sharia is deemed insufficient to assume that the Indonesian Government's SSN Program is following the concept of dharurriyatul khams. While the other three elements of maqashid sharia, namely religion, mind, and descent, are not well covered in the SSN programs. The welfare described in the maqashid sharia cannot be fulfilled without accomplishing the five aspects that are interrelated and complementary (Chapra, 2008). This is evident from the government's appeal to close mosques and limit congregational access to the mosque (MUI Fatwa No 14 of 2020, Government Letter number $451 / 7809 / 012 / 2020)$ that has caused a lot of resistance from the community. 
The Indonesian Mosque Council of East Java province stated that $60 \%$ of mosques did not comply with the appeal and preferred to open mosques as normal conditions (DMI, 2020). The Indonesian Mosque Council argued that no mosque became a large cluster for the spread of COVID 19 among the community. Although finally, the government relented by allowing the opening of mosques with health protocols, the congregation could not keep their distance in the implementation process, especially during Friday prayers. On the other hand, the absence of synergy between mosque management, mosque councils, zakat institution, government, and other related institutions to optimize the distribution of social programs has resulted in many misdirections of aid beneficiaries. The mosque is the center of community gathering, so that data collection on aid receivers will be more valid if it is carried out at the mosque.

In the aspect of protecting lives, the government has issued several policies that can be mapped into 2 focuses: (1) Treatment for people infected with COVID-19 and, (2) Prevention for people who have not been infected. Affordable health facilities have been provided by the government during this pandemic and are equipped with various information media to educate the public to maintain distance, wear masks, leave the house only if necessary, and other health protocols to prevent the spread of COVID-19.

Meanwhile, in the aspect of intellectual protection, the government carries out online learning and teaching activities. In its implementation, there has been a decline in education quality due to the limitations of online learning media (internet networks and devices). There are still many teachers and students who do not master online media. Many students cannot focus on online learning methods. This is exacerbated by unavailability of self-development facilities (soft and hard skills) that can be used by the community. Further, there is no synergy between education and training service providers and social institutions.

In protecting the family offsprings, no parameters have been met, starting from facilities to reduce stunting, malnutrition, and psychological disorders. These problems are neglected because they are considered irrelevant during the COVID-19 pandemic. Facilities for children with physical and mental disabilities cannot be properly accommodated. On the other hand, the increase in domestic violence, child neglect, and abortion during the COVID-19 pandemic did not receive a serious response from the government. This has an impact on the future sustainability of Indonesian communities.

In the aspect of protecting assets/property, the government has assisted in providing direct cash assistance (Bantuan Langsung Tunai/BLT), tax incentives, credit incentives, and electricity subsidies. However, education to the beneficiaries has not been carried out so that the impact on the assistance's sustainability is questionable. Many supports provided by the government are used for consumptive purposes compared to business capital to generate community independence.

The lack of fulfillment for aspects of maqashid sharia indicates that the SSN program issued by the government is still not optimal. It can be said that the SSN program's implementation has not been able to solve the social and economic problems caused by the COVID-19 Pandemic. This was exacerbated by the slow implementation of the program so that the community's dharurriyah needs were not immediately met. Thus, clear achievement parameters, integrated planning, swift and transparent program implementation, and monitoring of program operations are essential for a better SSN program implementation.

\section{CONCLUSION}

Islam recognizes the concept of maqahsid sharia, which is the basic framework for human life that can be used as a reference in the formulation of public policies. The Indonesian government policy that created the Social Safety Net (SSN) program to deal with the COVID-19 pandemic needs improvement.

The result of this study is the SSN program only focuses on protecting life and property. When referring to the aspect of needs required in the Islamic Maqashid Concept, it should fulfill the five components of Dharurriyatul Khams (Religion, Soul, Intellect, Descendants, and Wealth/Property). The absence of several aspects of the maqashid sharia in the SSN program is an important note to evaluate. This study seeks to provide a critical review (note) of the SSN programs provided for communities affected by the COVID-19 pandemic.

This study's limitation is the limited research and data collection process due to the COVID 19 pandemic so that it is unable to reach a more comprehensive problem to produce comprehensive of critical review of a Social Safety Net program. Therefore, further research is expected to develop a Social Safety Net (SSN) model based on Maqashid Sharia to provide integrated parameters and 
mechanisms for the government to compile an efficient, effective, and optimal SSN program.

\section{REFERENCES}

[1] A. M. Al-Awadhi, K. Alsaifi, A. Al-Awadhi, and S. Alhammadi, "Death and contagious infectious diseases: Impact of the COVID19 virus on stock market returns," J. Behav. Exp. Financ., 2020, doi: 10.1016/j.jbef.2020.100326.

[2] H. Alderman and J. Hoddinott, "GrowthPromoting Social Safety Nets," Int. Food Policy Res. Inst., 2007.

[3] D. H. Autor and M. G. Duggan, "The growth in the social security disability rolls: A fiscal crisis unfolding," J. Econ. Perspect., vol. 20, no. 3, pp. 71-96, 2006, doi: 10.1257/jep.20.3.71.

[4] A. Banerjee, "Social Safety Net Programs and Household Behavior," 2019.

[5] A. Barrientos and D. Hulme, "Social protection for the poor and poorest in developing countries: Reflections on a quiet revolution," Oxford Dev. Study, vol. 37, no. 4, pp. 439-456, 2009.

[6] A. Barrientos and D. Hulme, "Chronic poverty and social protection: Introduction," Eur. J. Dev. Res., vol. 17, no. 1, pp. 1-7, 2005, doi: 10.1080/09578810500066423.

[7] A. Beauchamp and M. Wagner, "Is there adverse selection in the U.S. social security system?," Econ. Lett., vol. 189, p. 108995, 2020, doi: 10.1016/j.econlet.2020.108995.

[8] D. E. Bloom, D. Cadarette, and J. P. Sevilla, "Epidemics and Economics: New and resurgent infectious diseases can have farreaching economic repercussions," Finance Dev., vol. 55, no. 2, pp. 46-49, 2018.

[9] M. U. Chapra, "The Islamic Vision of Development in the Light of," Islam. Res. Train. Inst., p. 11, 2008.

[10] M. U. Chapra, "Islam and The Economic Challenge," Int. Inst. Islam. Thought, 1994.

[11] J. M. Conway and A. I. Huffcutt, "A Review and Evaluation of Exploratory Factor Analysis Practices in Organizational Research," Organ. Res. Methods, vol. 6, no. 2, pp. 147-168, 2003, doi: $10.1177 / 1094428103251541$.

[12] E. Cottle Hunt and F. N. Caliendo, "Social Security reform: three Rawlsian options," Int. Tax Public Financ., vol. 27, no. 6, pp. 1582-1607, 2020, doi: 10.1007/s10797020-09607-4.
[13] V. Darwis and A. R. Nurmanaf, "Pengentasan Kemiskinan: Upaya yang Telah dilakukan dan Rencana Waktu Mendatang," Forum Penelit. Agro Ekon., vol. 19, no. 1, p. 55, 2016, doi: 10.21082/fae.v19n1.2001.55-67.

[14] A. E. de Wind, S. Brage, F. Latil, and N. Williams, "Transfer of tasks in work disability assessments in European social security," Eur. J. Soc. Secur., vol. 22, no. 1, pp. 24-38, 2020, doi: $10.1177 / 1388262720910307$.

[15] F. Eggers, "Masters of disasters? Challenges and opportunities for SMEs in times of crisis," J. Bus. Res., vol. 116, no. May, pp. 199-208, 2020, doi: 10.1016/j.jbusres.2020.05.025.

[16] V. Y. Fan, D. T. Jamison, and L. H. Summers, "Pandemic risk: how large are the expected losses?," Bulletin of the World Health Organization, 2018. https://www.ncbi.nlm.nih.gov/pmc/articles/ PMC5791779/.

[17] M. Fauzia, "Pencairan Anggaran Covid-19 Masih Kecil, Sri Mulyani Tak Salahkan Kemenkes," Kompas, 2020.

[18] S. Gupta, B. Clements, and G. Inchauste, "Safety Nets and Implementation of Macroeconomic Adjustment Programmes," Econ. Polit. Wkly., vol. 38, no. 37, pp. 38973907, 2003.

[19] H. F. Hsieh and S. E. Shannon, "Three approaches to qualitative content analysis," Qual. Health Res., vol. 15, no. 9, pp. 12771288, 2005, doi: 10.1177/1049732305276687.

[20] IEG, Social Safety Nets: An Evaluation of World Bank Support, 2000-2010. 2011.

[21] D. Ivanov, "Predicting the impacts of epidemic outbreaks on global supply chains: A simulation-based analysis on the coronavirus outbreak (COVID-19/SARSCoV-2) case," Transp. Res. Part E Logist. Transp. Rev., vol. 136, no. March, p. 101922, 2020, doi: 10.1016/j.tre.2020.101922.

[22] Kemensos, "Solusi Hadapi Permasalahan Sosial Bantuan Sosial Tunai (Bansos Tunai)," Puspensos Kementrian Sosial, 2020.

https://puspensos.kemsos.go.id/solusihadapi-permasalahan-sosial-bantuan-sosialtunai-bansos-tunai. 
[23] C. Lawley, "Potential impacts of COVID-19 on Canadian farmland markets," Can. J. Agric. Econ., vol. 68, no. 2, pp. 245-250, 2020, doi: 10.1111/cjag.12242.

[24] F. Mackintosh and J. Blomquist, "Assisting the Poor with Cash: Design and Implementation of Social Transfer Program," World Bank Inst., no. 5, 2003.

[25] P. Majumder and S. Begum, "The Old Age Allowance programme for the poor elderly in Bangladesh," 2008.

[26] M. Mannan, "Safety net programs in Bangladesh: Assessing the performance of selected programs," no. 5, 2010.

[27] B. Mazumder, "Fortunate sons: New estimates of intergenerational mobility in the united states using social security earnings data," Rev. Econ. Stat., vol. 87, no. 2, pp. 235-255, 2005, doi: 10.1162/0034653053970249.

[28] S. Paitoonpong, S. Abe, and N. Puopongsakorn, "The meaning of 'social safety nets," J. Asian Econ., vol. 19, no. 56, pp. 467-473, 2008, doi: 10.1016/j.asieco.2008.09.011.

[29] Permenakertrans, Komponen dan Pelaksanaan Tahapan Pencapaian Kebutuhan Hidup Layak. Indonesia, 2012.

[30] M. Ravallion, "The Debate on Globalization, Poverty, and Inequality: Why Measurement Matters," R. Inst. Int. Aff., vol. 79, no. 4, pp. 739-753, 2003, doi: 10.1093/acprof:oso/9780199558032.003.00 02.

[31] Satuan Tugas Penanganan Covid-19, "Infografis Covid-19 di Indonesia," 2020. https://covid19.go.id/p/berita/infografiscovid-19-02-agustus-2020.

[32] S. Sumarto, A. Suryahadi, and W. Widyanti, "Assessing the Impact of Indonesian Social Safety Net Programs on Household Welfare and," 2004.

[33] G. Sumodiningrat, "Jaring Pengaman Sosial Dan Pemberdayaan Masyarakat," J. Indones. Econ. Bus., vol. 14, no. 3, 1999.

[34] E. Tesliuc, "Social Safety Nets in OECD Countries. Primer Notes no. 25," World Bank Inst., no. 25, 2006.

[35] E. Tesliuc, A. Ouerghi, C. del Ninno, and M. Grosh, The Design and Implementation of Effective Safety Nets: For Protection \& Promotion. 2008.

[36] I. W. Wenagama, "Dampak Program Pemberdayaan Masyarakat," Ef. Dan
Dampak Progr. Nas. Pemberdaya. Masy., pp. 1658-1685, 2017.

[37] World Bank, The State of Social Safety Nets. 2018.

[38] M. Zain, "Reformasi Pengentasan Kemiskinan: dari Pendekatan Ekonomi ke Pendekatan Kesejahteraan," Masyarakat, Kebud. dan Polit., vol. 12, no. 4, pp. 79-96, 1999.

[39] M. Zakaria and N. A. A. Malek, "Effects of human needs based on the integration of needs as stipulated in maqasid syariah and maslow's hierarchy of needs on zakah distribution efficiency of asnaf assistance business program," J. Pengur., vol. 40, pp. 41-52, 2014, doi: 10.17576/pengurusan2014-40-04.

[40] M. Zakaria, M. S. A. Yusoff, and Z. Sanusi, "Governance and Efficiency of Zakah Distributions Based on the Dire Necessities of Maqasid Al-Syariah," Int. J. Financ. Res., vol. 10, no. 5, pp. 191-203, 2019, doi: 10.5430/ijfr.v10n5p191.

[41] D. Zhang, M. Hu, and Q. Ji, "Financial markets under the global pandemic of COVID-19," Financ. Res. Lett., vol. 36, p. 101528, 2020, doi: 10.1016/j.frl.2020.101528. 